\title{
Analysis of developing the third party logistics enterprise in e-commerce age
}

\author{
Xu Lie \\ Economic and Trade College \\ Nanjing Institute of Railway Technology \\ Nanjing 210031,China \\ e-mail:xulie005@163.com
}

\begin{abstract}
With the rapid development of information technology, e-commerce as a new business mode, has been fully penetrated into people's lives. While successful e-commerce activities require logistics support. The author analyses China's logistics status, and discusses the logistics demand of e-commerce enterprise. Then the discussion of developing the third party logistics enterprise in e-commerce age is shown.
\end{abstract}

Keywords-e-commerce the third party logistics enterprise discussion

\section{I.RESEARCH BACKGROUND}

With the rapid development of information technology, e-commerce as a new business mode has been fully penetrated into people's lives. The data of China Electronic Commerce Research Center shows: In 2011 the market of electronic Commerce has reached 7 trillion yuan, which has 46.4\% growth in 2010. It is shown that China's e-commerce industry has been integrated into the explosive growth after the accumulate steadily. According to the forecast, the e-commerce market in China will continue will bigger in few years. It can be said that China has entered the era of electronic commerce. The electronic commerce generally includes four elements: business flow, information flow, logistics, and cash flow. Logistics as one of the four substances is the key point of e-commerce. During the e-commerce, consumers get the ownership of the goods by clicking the mouse; while the e-commerce has not completed, stilling goods and services really transferred to consumers through logistics. So no modern logistics, and no e-commerce.

Though China has great growth in online shopping volume, there are some disharmonious phenomena are often seen on the peak trading that is goods can not be promptly sent to consumers. The emergence of these phenomena shows that logistics industry can not provide ancillary services for the rapid development of e-commerce. If the phenomena exist for a long time, the development of e-commerce will slow. In the era of e-commerce, logistics industry is facing many challenges, but it's also an opportunity. Successfully solving the logistics problems of the era of e-commerce can not only promote the development of e-commerce, will also promote the further development of the logistics industry in China.

\section{II.DEVELOPMENT STATUS OF LOGISTICS INDUSTRY IN CHINA IN THE ERA OF E-COMMERCE}

A.E-commerce and logistics development has obvious regional characteristics

E-commerce and logistics development has obvious regional characteristics, which has two reasons: first, the development of e-commerce is close related to the level of regional economic development. The eastern part of our country's e-commerce development is faster than the middle and the western, corresponding of economic development. Ali Research Center in Beijing released 《2011 network operators Development Index 》launched the top 100 cities that the e-commerce businesses is grow fast. The top 10 is Guangzhou, Shanghai, Beijing, Hangzhou, Shenzhen, Suzhou, Nanjing, Jinhua, Dongguan and Wuhan. In the ten cities, only Wuhan is belonging to the central region, the remaining nine cities are in eastern coastal areas. Second, there is a wide gap between the eastern, central and western about the logistics infrastructure layout. The eastern develop faster, the central region is the middle of the second, and the western is the last which only contain $16 \%$ of China's Logistics facilities. The layout effect the quality of service of western's logistics enterprises.

$B$. Logistics has become the short board of the development of e-commerce businesses

China's e-commerce business develops fast in recent years, and the logistics has a huge contribution to it. But now logistics has become the short board of the e-commerce businesses, because the logistics development is much slower than the e-commerce's. Now the growth of e-commerce is $200-300 \%$, while the logistics' is $40 \%$. In China, most of the e-commerce businesses choose to outsource logistics to the third party logistics enterprises, but third party logistics enterprises is not satisfied. Some company exist disorderly competition. Some company's level of information technology is lower. Many consumers are dissatisfied with the third party logistics' quality of service. Above the problems would be effect the further development of e-commerce business in China. China Electronic Commerce Research Center forecasts consumers will pay more attention to the logistics' quality of service and others in the future e-commerce's trade. Logistics would be an important way for e-commerce enterprises to expand their business scope, enhance competitiveness.

C. Lacking compound talent of e-commerce and logistics 
The logistics in e-commerce's trade is cross point, which need the worker have more talent. The person working in the area should obtain the theory of e-commerce, Internet technology and modern logistics thought. In China some workers of the third party logistics enterprises have non-professional knowledge, which Influence whole company's work efficiency.

\section{LOGISTICS DEMAND ANALYSIS OF E-COMMERCE ENTERPRISE}

At present, logistics service providing in e-commerce trade are almost express company, which provide temporary storage and distribution. They couldn't provide personalized service for e-commerce enterprise. The mode is not suit for some e-commerce enterprises. Accompanied by the growth of e-commerce enterprise's Shipments, tradition third party logistics become pay attain to the e-commerce area. Compared with traditional warehousing management, logistics in e-commerce trade has it own characteristic. The third party logistics company, who care the e-commerce area, should analysis needs of e-commerce enterprise's logistics demand. The needs are as follows:

\section{A.Orders'reaction time shorter}

The e-commerce enterprise have great hope on the rate of order reaction, because the speed and convenient is the reason consumer chose online shopping. If the consumers have the order, while the goods couldn't be delivery on time. Then people will not shopping online again. Anyway, the electronic commerce enterprise pay great attain to the orders'reaction time and distribution.

\section{B.Flexible logistics services}

China's e-commerce activities are usually frequent in the holidays, leading to the order quantity changes larger. The express often serve for a number of e-commerce enterprises, so the service can't be on time in holiday. The e-commerce enterprises need the third party logistics company that can offer flexible logistics services, which satisfy the demand between the normal business and the peak.

\section{Providing value added service}

Some e-commerce enterprises following the development become follow with interest the third party logistics enterprises that could provide value added service. On one hand, the e-commerce enterprise need the third party logistics providing on time tracking orders, good after-sales service, consumers' response, and the information of stock etc. On the other hand, more and more e-commerce enterprise care about logistics cost. Some huge e-commerce enterprise dissatisfied the express, and they have interest in the third party logistics that could cut the cost. While some e-commerce enterprise even dissatisfied the third party logistics. They chose to building the logistics system by their own.

\section{IV.THE DISCUSSION OF DEVELOPING THE THIRD PARTY LOGISTICS ENTERPRISES IN E-COMMERCE AGE}

When the third party logistics enterprises serve for the e-commerce enterprise, they could use those tactics, as follows:

\section{A.Providing value added service}

Now the service for e-commerce enterprise is almost based on warehousing, transportation, distribution and other basic services, but value added service is really needed. The third party logistics enterprises should offer some personalized service according the e-commerce enterprises' require. It could be in commodity trading link, such as providing open-package inspection, trying to experience, door-to-door replacement, site installation etc. It also could be on the aspect of personalized server time, such as evening distribution, distribution in a predetermined time etc. Above the service mode imply that the third party logistics enterprises could provide multi-functional logistics service to promote the service quality and customer satisfaction.

\section{B.Distribution model innovation}

The distribution model in e-commerce trade is distribution by own and the third party logistics distribution. The third party logistics enterprises could innovate the distribution model, such as building logistics alliance. The logistics alliance means number of third party logistics enterprises work together. In alliance a company could complete his own good business; the business he is not good at could get to his alliance. Maybe the mode could promote the productivity and reduce the cost.

\section{C.Strengthen the construction of information technology}

It is very important to building logistics information system. The construction of logistics information include two elements: first, applying the bar code technology, EDI technology, RFID technology, voice recognition technology and GPS technology, and build intelligent distribution center gradually. Second, establishing modern logistics information system. The functions of the logistics information system include information collection, information processing, control and management. The whole logistics activity should be controlled by logistics information system. The information such as products number, variety of goods, storage, and travel position could be getting on time.

\section{D.Enhance employees training}

The worker in the third party logistics enterprises need have the knowledge both e-commerce and logistics. The employees need Computer skills, the logistics equipment operation skills, and the theory of logistics management. So the third party logistics enterprises need carry out all kinds of logistics vocational training regularly, in order to improving employees’ quality.

\section{REFERENCES}

[1].Jia xiaobo. The Development Strategies of Third-party Logistics Under E - commerce Environment [J].Friend of Science Amateurs ,2011(10).p131-132

[2]. Wu junrui. The study of e-commerce and distribution model [J]. Technology Guide 2012（5）. P114-115 
[3]. Hong Lizhen, Xu junjie, LI yiliang.The analysis of e-commerce and logistics integrating model [J].China Management Informationization 2012(18) P88-89 